\title{
DINÂMICA GEOMORFOLÓGICA DA DISSECAÇÃO DOS PLANALTOS NO ENTORNO DA HIDRELÉTRICA DE ITAOCARA, RJ
}

\author{
Marcelo MotTA De Freitas ${ }^{1}$ \\ FELIPE FRAIFELD ${ }^{2}$ \\ FELIPE NORONHA ${ }^{3}$ \\ Pontifícia Universidade Católica do Rio de Janeiro
}

\begin{abstract}
Resumo: O presente artigo trata do estudo de caso do projeto de instalação da Usina Hidrelétrica (UHE) de Itaocara, localizada na região Noroeste Fluminense, próximo ao baixo curso do rio Paraíba do Sul, a montante do seu encontro com o rio Pomba. O objetivo deste trabalho consiste na elaboração do mapeamento geomorfológico da área no entorno da UHE Itaocara, com vistas ao entendimento da evolução dinâmica desta paisagem e dos efeitos que o empreendimento pode causar sobre os processos erosivos atuantes na área. Os resultados foram analisados em função dos processos evolutivos de dissecação deste relevo que agem nas áreas de influência do empreendimento, a partir de sua divisão em domínios geomorfológicos. Foram delimitados e apresentados dez domínios geomorfológicos que se baseiam em uma abordagem que considera a importância do nível de base local na compartimentação do relevo. Nesse sentido, tais domínios são resultantes da evolução geomorfológica de longo tempo, influenciados pelos pulsos erosivos associados ao rebaixamento dos níveis de base locais e sua contribuição para o entendimento das dinâmicas erosivas deflagradas na área de estudo.
\end{abstract}

\section{GEOMORPHOLOGICAL DYNAMICS OF DISSECTING PROCESSES IN THE UPLANDS SURROUNDING THE ITAOCARA HYDROELETRIC, RJ}

Abstract: This article focuses on the case study of the installation project of Itaocara hydroelectric power plant (HPP), located in the region of northwest Rio de Janeiro, near the lower course of the Paraíba do Sul River, Brazil. The aim of this work is to understand the dynamic evolution of this

\footnotetext{
${ }^{1}$ Professor doutor do Departamento de Geografia e Meio Ambiente da PUC-Rio e coordenador do grupo de pesquisa Morfotektos, PUC-Rio. Contato: marcelomotta@puc-rio.br.

${ }^{2}$ Geógrafo, pesquisador do grupo de pesquisa Morfotektos, PUC-Rio. Contato: felipefrai@gmail.com.

${ }^{3}$ Professor do Departamento de Geografia e Meio Ambiente da PUC-Rio, pesquisador do grupo de pesquisa Morfotektos, PUC-Rio, e analista ambiental da Prefeitura do Rio de Janeiro. Contato: noronhaandrade@gmail.com.
} 
landscape and the effects that the project may have on its erosion processes. This was achieved through the development of the geomorphological mapping of the area surrounding Itaocara HPP. The results were then analyzed in terms of evolutionary processes of this relief dissection through its division into geomorphological domains. Ten geomorphological domains were presented and described, based on an approach that considers the importance of the knickpoints on the partitioning of relief. In this sense, these areas are the result of the long termgeomorphological evolution, influenced by erosive pulses associated with the lowering of local base levels, and its contribution for the understanding of erosive dynamics along the study area.

\section{Introdução}

Os empreendimentos hidrelétricos são intervenções de grande influência na dinâmica das redes de drenagem e interagem com os aspectos geomorfológicos já constituídos da região em que se instala. Portanto, o conhecimento prévio destas feições e suas dinâmicas de evolução são primordiais para o entendimento dos efeitos de uma intervenção direta sobre a calha fluvial de qualquer rio. O presente artigo trata do estudo de caso do projeto de instalação da Usina Hidrelétrica (UHE) de Itaocara, localizada na região Noroeste Fluminense, próximo ao baixo curso do rio Paraíba do Sul, a montante do seu encontro com o rio Pomba. Localizado na fronteira com o estado de Minas Gerais, porção reversa da Serra do Mar, este trecho da bacia é um ambiente geomorfológico no qual predominam colinas côncavoconvexas com diferentes amplitudes de relevo, em que a distância entre os divisores de drenagem e o fundo de vale pode variar de duzentos metros a até seiscentos metros, dependendo do domínio morfológico.

O objetivo deste trabalho consiste na elaboração do mapeamento geomorfológico da área no entorno da UHE Itaocara, buscando o entendimento da evolução dinâmica desta paisagem e dos efeitos que o empreendimento pode causar sobre os processos erosivos atuantes na área. Para tal, foi definida a área de influência do empreendimento, objeto da presente investigação. Nesse contexto, o levantamento de feições erosivas e dos seus processos correlatos, analisados a partir da escala de bacias hidrográficas, atua como instrumento-chave para o levantamento e avaliação das áreas cuja ocupação e uso inadequados resultariam em problemas em diversas dimensões do espaço geográfico aí constituído.

Cabe ressaltar que, devido ao potencial de alterar dinâmicas geomorfológicas em uma dada paisagem, o empreendedor deve executar seu gerenciamento de maneira a evitar riscos e/ou mitigar possíveis impactos. Ambos, se mal gerenciados, podem representar eventos críticos que possuem o potencial de afetar a vida da população local ou até mesmo interromper as atividades do próprio empreendimento. Nesse contexto, os estudos ambientais requeridos pela legislação brasileira englobam diversos aspectos de maneira a detalhar o contexto no qual o empreendimento se insere, seus possíveis impactos e mitigações. No caso dos estudos geomorfológicos, as principais questões se referem às alterações na dinâmica das oscilações do lençol, 
à interferência sobre os knickpoints devido à reativação de processos erosivos que aparentemente estavam estabilizados, ao surgimento de novas frentes erosivas e aos novos ajustes erosivos e deposicionais em função do alagamento artificial do reservatório.

Nesse sentido, o estudo sobre os processos erosivos se associam à evolução da paisagem geomorfológica em escalas temporais de longa duração. Assim, as abordagens de Ab'Saber (2003) em Domínios de Natureza no Brasil nos convidam a uma visão mais integrada da paisagem, bem como seus trabalhos relativos a casos específicos da geomorfologia, a exemplo dos efeitos de captura de drenagem que demonstram a dinâmica de evolução das paisagens, associadas a descrição de formas.

Segundo Ab'Saber (1957), destaca-se dentre os sistemas de capturas no rio Paraíba do Sul a captura do Alto Tietê, onde estão envolvidas questões associadas à quebra do continente Gondwana, formação do Rift Sudeste e rebaixamento do nível de base geral da região. Dessa forma, os processos analisados em uma escala têm correspondência a processos em outras escalas de paisagem que devem ser integradas em sua interpretação. Especificamente no médio vale do rio Paraíba do Sul, as colisões continentais formadoras do continente Gondwana no ciclo Brasiliano (SCHOBBENHAUS \& CAMPOS, 1984; SCHOBBENHAUS \& NEVES, 2003) foram responsáveis por diversas estruturas tectônicas e formação de litotipos que influenciam profundamente a evolução da rede de drenagem no vale do rio Paraíba do Sul (HEILBRON et al., 1995; HEILBRON et al., 2004). Da mesma forma, foram contundentes os processos oriundos da abertura do Oceano Atlântico na formação de planos de fraturas e falhas resultantes da tectônica rúptil, que ainda escalonou o relevo nos sistemas de horsts e grabens, provenientes do Rifteamento (RICCOMINI et al., 2004; ASMUS \& FERRARI, 1978; ALMEIDA, 1976). Sendo assim, o processo de evolução da rede de drenagem após todos esses eventos tectônicos sobrepuseram desenhos na esculturação das formas das encostas que de fato seguiram os principais planos de fraqueza deste complexo substrato geológico. O papel dos níveis de base locais foi fundamental para a definição das amplitudes de relevo e para a propagação de pulsos erosivos. Estes pulsos evoluíram ao longo do tempo, ajustando os canais fluviais e encostas aos novos níveis de base impostos pelos eventos tectônicos (FREITAS, 2007; FREITAS et al., 1999).

\section{Área de Estudo}

A área de estudo se localiza no médio/baixo curso do rio Paraíba do Sul, nas proximidades da cidade de Itaocara, Estado do Rio de Janeiro, entre os meridianos $42^{\circ} 55^{\prime} 41^{\prime \prime}$ e $42^{\circ} 01^{\prime} 24^{\prime \prime}$ e os paralelos $21^{\circ} 31^{\prime} 24^{\prime \prime}$ e $22^{\circ} 00^{\prime} 11^{\prime \prime}$, e possui $2.185 \mathrm{~km}^{2}$ 
de extensão (Figura 1). O principal acesso à área, saindo da cidade do Rio de Janeiro, se dá pelas rodovias BR116, BR 393 e RJ116.
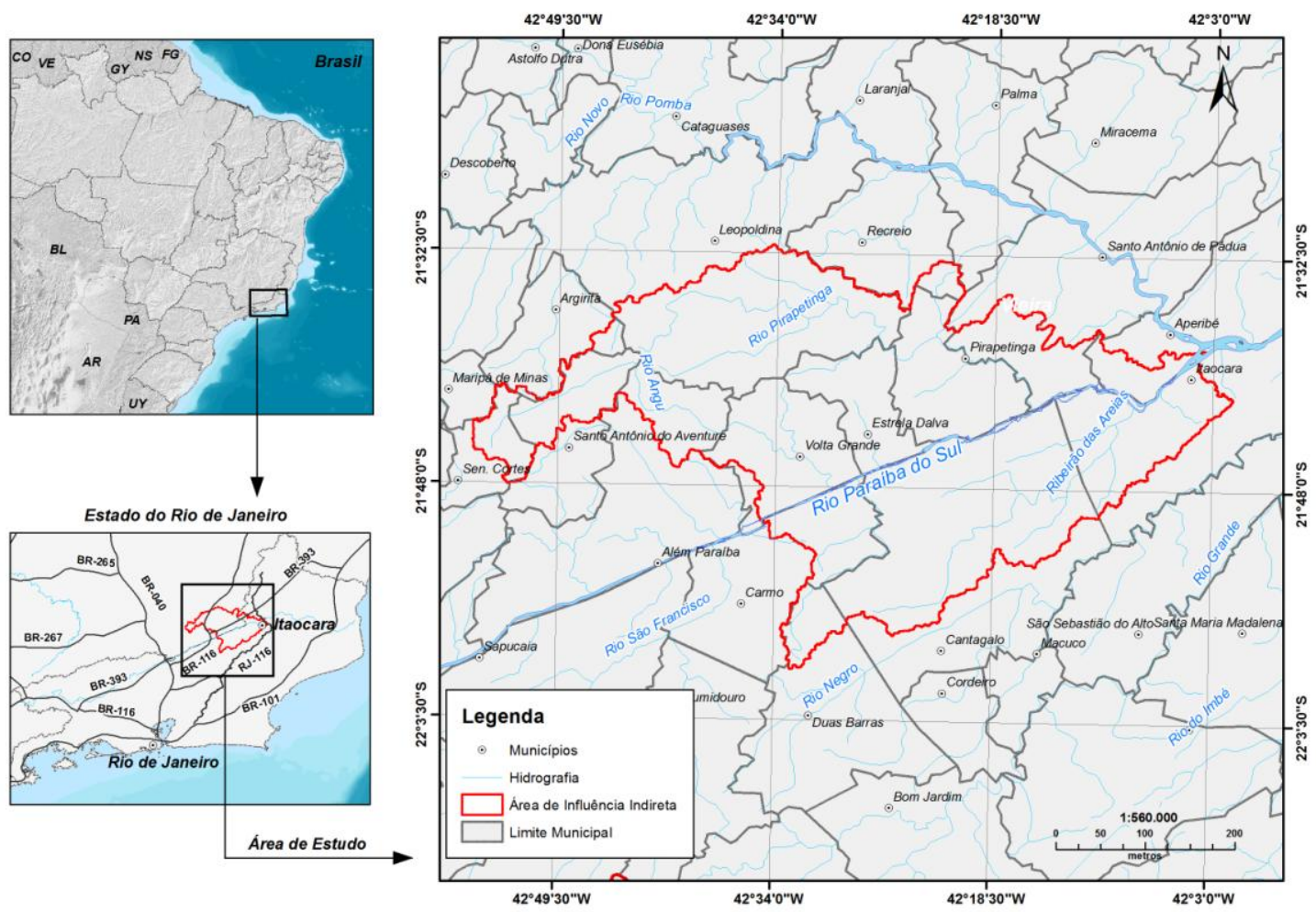

Figura 1: Mapa de localização da área de estudo.

O escalonamento topográfico gerado pelos sucessivos níveis de base do rio Paraíba do Sul define compartimentos de funcionalidade geomorfológica específica. A área de estudo situa-se acima do nível de base formado pelas corredeiras próximas à cidade de Itaocara e estende-se até ao próximo nível de base a montante, na Ilha dos Pombos, onde foi construída a hidrelétrica homônima. Este compartimento da bacia foi definido como área de influência do empreendimento, abrangendo as bacias de drenagem afluentes a este trecho do canal do rio Paraíba do Sul.

\section{Metodologia}

A abordagem geomorfológica realizada sobre a paisagem em questão envolve a metodologia de observação, utilizada amplamente nas décadas de 1950 e 60, e a abordagem sistêmica mais recente, que busca na paisagem as inter-relações entre os elementos físicos e biológicos da natureza e suas interações com as atividades 
humanas no espaço e no tempo. A realidade se coloca de maneira em que é imprescindível complementar abordagens metodológicas para a busca de um entendimento integrado.

Somado a essa percepção foram também adotados os preceitos propostos por Ross (2000), quem incorpora as condicionantes do substrato geológico na esculturação das formas da superfície, percebendo a influência da litoestrutura nas feições encontradas. Sendo assim, uma abordagem evolutiva foi aqui proposta, buscando o entendimento dinâmico e evolutivo da paisagem ao longo do tempo, relacionando as formas de relevo atuais com os processos erosivos responsáveis pela dissecação do trecho de relevo analisado.

Para o levantamento geomorfológico deste estudo, foi adotada como base a classificação elaborada pelo CPRM para o Mapa Geomorfológico do Estado do Rio de Janeiro, que utilizou a metodologia de Ross (1990). Sendo assim, o mapeamento foi alicerçado nas relações entre degradação (denudação) e agradação (deposição) que resultou em uma classificação de sistemas de relevo. Além da classificação de morfologias elaborada pelo CPRM, foi proposto um mapeamento geomorfológico na escala 1:50.000, definindo domínios específicos para a área de estudo, uma vez que as abordagens feitas pelo CPRM englobaram os estados do Rio de Janeiro e Minas Gerais em escala menor (1:500.000).

Dessa forma, a elaboração do trabalho se inicia com a apresentação de uma revisão bibliográfica sobre o contexto geotectônico no qual a hidrelétrica está inserida, seguida da apresentação do mapeamento e classificação geomorfológica elaborada para a área de influência do empreendimento. Além disso, foram mapeados e discutidos os processos erosivos existentes na área, revelando seus mecanismos, causalidades, padrões e processos.

Para tanto foram realizadas três campanhas de campo de dez dias cada uma, com o objetivo de refinar os mapeamentos existentes, vistoriar pontos de verificação da verdade terrestre, observar e interpretar as feições erosivas na área de estudo. Em gabinete, foram realizados os cruzamentos dos bancos de dados geográficos e georreferenciados em ambiente digital, no software ESRI ${ }^{\mathrm{TM}}$ ArcGIS 9.3. No campo, os pontos foram coletados e plotados com GPS Garmin ${ }^{\text {TM }}$ Etrex Vista Hcx. Esta sistemática de inserção dos dados estudados previamente e os obtidos em campo no ambiente digital, seguida de sua manipulação e análise, resultou na confecção do mapa de domínios geomorfológicos. 


\section{Revisão Bibliográfica}

\section{Contexto Geotectônico}

Geologicamente, a área do empreendimento encontra-se inserida na porção sudeste do país, na denominada "Faixa Móvel Ribeira". Esta faixa móvel contida na província da Mantiqueira possui rochas geradas no ciclo Orogênico Brasiliano (Proterozoico Superior 700-450 Ma), caracterizado pelo intenso metamorfismo, deformação das litologias supracrustais e extensas porções do embasamento, seguido por consecutivos pulsos de granitização (sin, tarde e pós-tectônicos) com estruturas geológicas preferencialmente na direção NE-SW (Nordeste-Sudoeste) (HEILBRON et al., 2004).

Após estes eventos colisionais de amalgamento do continente e milhares de anos de estabilidade crustal, há cerca de 237 milhões de anos, em meados do período Triássico, o megacontinente começou a se fraturar e, no Mesojurássico (175 Ma.), iniciou-se a abertura do Oceano Atlântico. Junto à abertura do Atlântico, a intensa atividade tectônica desenvolveu riftes na região do Atlântico-Sul, associados a diques de diabásio e derramamentos de basalto, remobilizando falhas antigas e gerando diversos sets de fraturamento (ALMEIDA, 1976; RICOMINNI et al., 2004).

O rifteamento continental do sudeste do Brasil formou os Horsts e os Grabens (soerguimentos e rebaixamento), que hoje se apresentam trabalhados pelo longo processo erosivo, representados na paisagem pelos grandes alinhamentos serranos da Serra do Mar e Mantiqueira (Horsts) e pelas regiões abatidas (Grabens) do vale do rio Paraíba do Sul e baixada fluminense no entorno da Baía de Guanabara. Os grabens formados pelo processo de rifteamento constituem-se como armadilhas para a sedimentação de importantes bacias sedimentares locais, como São Paulo, Taubaté, Resende, Santos e Campos, sendo estas duas últimas submersas.

Estes eventos tectônicos estruturaram, na região do empreendimento, o Graben de Itaocara (TUPINAMBÁ et al., 2003), consistindo em uma área abatida em relação à topografia regional. Esta feição tectônica define a convergência de fluxos e materiais, ocasionando um trabalho erosivo mais intenso ao longo do tempo geomorfológico em sua direção. Segundo Tupinambá et al (2003):

O Graben de Itaocara consiste em uma depressão morfológica localizada na confluência dos rios Pomba e Paraíba do Sul, junto à cidade homônima no norte do estado do Rio de Janeiro. A área, sujeita a recorrentes inundações, é altamente dissecada e preenchida, parcialmente, por sedimentos fluviais e coluviais recentes. Seu embasamento pré-cambriano está fortemente controlado por estruturas (foliação, contatos, empurrões) de 
direção N40-60E, interceptadas por zonas de cisalhamento rúpteis-dúcteis, de direção NNW, que, provavelmente, sofreram várias fases de reativação.

Essas estruturas têm influência marcante na esculturação do relevo atual, sendo responsáveis pela orientação das redes de drenagem, feições do relevo e processos erosivos. O somatório das condições litológicas e estruturais do substrato geológico é, portanto, de fundamental importância na interpretação e diagnóstico geomorfológicos da área estudada.

\section{O Graben de Itaocara}

O compartimento topográfico definido pelo Graben de Itaocara é uma porção deprimida do baixo vale do rio Paraíba do Sul que apresenta um relevo de extenso domínio colinoso com alvéolos fluviais embutidos, inserido entre alinhamentos serranos de direção Nordeste. A evolução geomorfológica da região é marcada pelo recuo erosivo de sucessivos pulsos de dissecação relativos a processos de rebaixamento de níveis de base regionais.

Em geral, o manto de intemperismo, fruto das intempéries sobre o substrato geológico, ocorre na maioria das vertentes da bacia em questão, resultando em uma paisagem com afloramentos rochosos concentrados em pontos específicos onde o recuo erosivo está ativo. O recobrimento dos mantos de solo é variável em espessura, desde poucos centímetros nas altas encostas a poucos metros em direção aos fundos de vale, porém, de uma forma geral, apresenta pouca espessura. O trabalho erosivo sobre o material intemperizado, provocado por processos hidrológicos que respondem às estruturas do substrato geológico, geram uma morfologia no planalto intermontano relativa à ocorrência de complexos de rampa e coalescência associadas (MEIS et al.,1981; MOURA \& SILVA, 1998). As rampas são formadas por um complexo de camadas coluvionares, às vezes misturando-se a camadas aluvionares, concentradas no eixo de concavidades convergentes de fluxos hidrológicos e sedimentos. Os complexos de rampa, definidos por Meis et al. (1981), envolvem ainda as feições erosivas das altas encostas das concavidades. Estes complexos de rampas evoluem em direção aos divisores de drenagem, rebaixando-os e formando suas coalescências. O resultado desses processos na paisagem forma o que Ab'Saber denominou "Mares de Morros" (Figura 2), formas que, segundo o autor, se estendem por todo o Brasil Tropical Atlântico, presentes em diversos níveis topográficos (AB'SABER, 2003). 


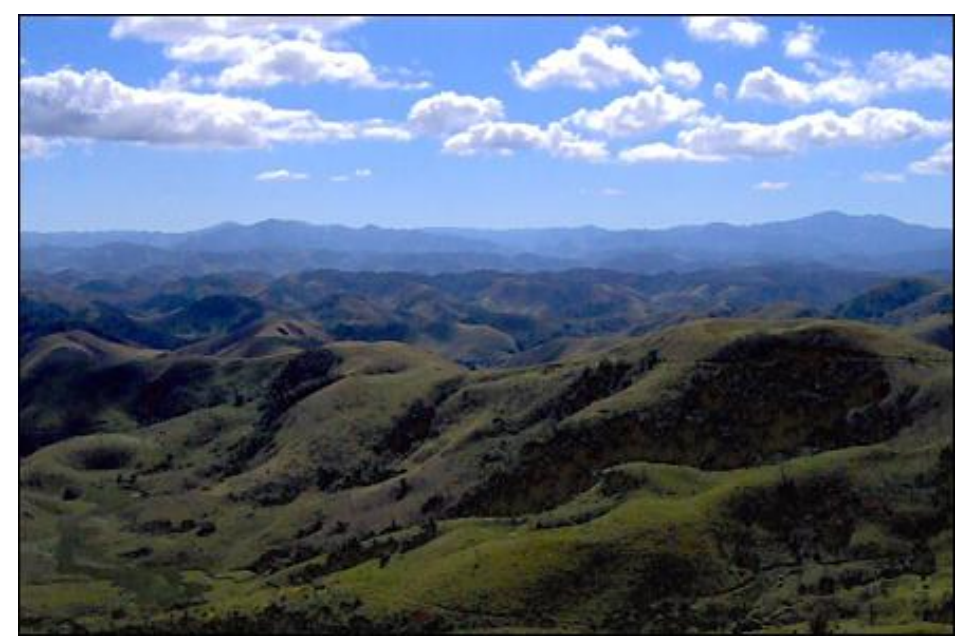

Figura 2: Aspecto da paisagem de "Mares de Morros" (AB'SABER, 2003) no planalto Atlântico Leste-Sudeste, com a presença das concavidades nas cabeceiras de drenagem, denominadas complexos de rampa por Meis et al. (1981).

As feições geomorfológicas resultantes do trabalho erosivo em direção ao graben, visto como o nível de base de referência para área de estudo, apresentam-se como relevos rebaixados, em maioria de geometria convexa, porém entremeada por reentrâncias côncavas. Nas mudanças de níveis topográficos para as áreas mais elevadas são encontrados afloramentos rochosos em escarpamentos para relevos suspensos, além de níveis de base locais em forma de cachoeiras.

As unidades litológicas revelam a orientação do trend principal das camadas com direção predominante NE. De forma geral, esta condição define pela erosão diferencial a orientação das principais serras, como as serras do Cascalho, do Português, do Prata, do Catete, Santa Cândida, do Gavião e da Bolívia, nas litoestruturas mais resistentes, e o alinhamento da calha do rio Paraíba do Sul nas zonas de fraqueza. Tupinambá et al. (2003) afirmam que:

Observa-se na paisagem geomorfológica, o forte condicionamento imposto pelo arcabouço tectônico da Faixa Ribeira, ressaltando o papel das unidades litológicas, aparentemente, mais resistentes à erosão, sustentando os alinhamentos serranos. A rede de drenagem apresenta um típico padrão em treliça, com canais orientados, principalmente, segundo as direções NE e NW, revelando o forte controle estrutural sobre a organização dos canais. Deste modo, os canais de direção NE, como a maior parte do rio Paraíba do Sul, são controlados pela direção da foliação principal (milonítica ou não), normalmente, de alto ângulo e pelos contatos litológicos, muitas vezes marcados por zonas de cisalhamento dúcteis. Já os canais 
de direção NW, como o rio Pomba, são condicionados pelas fraturas e falhas de alto ângulo.

No trecho delimitado como área de influência, a calha principal do rio Paraíba do Sul, como dito, obedece às estruturas de zonas de cisalhamento, falhamentos e foliação de direção nordeste - neste caso a zona de cisalhamento de Frecheiras e a Borda Tectônica Central (Figura 3).

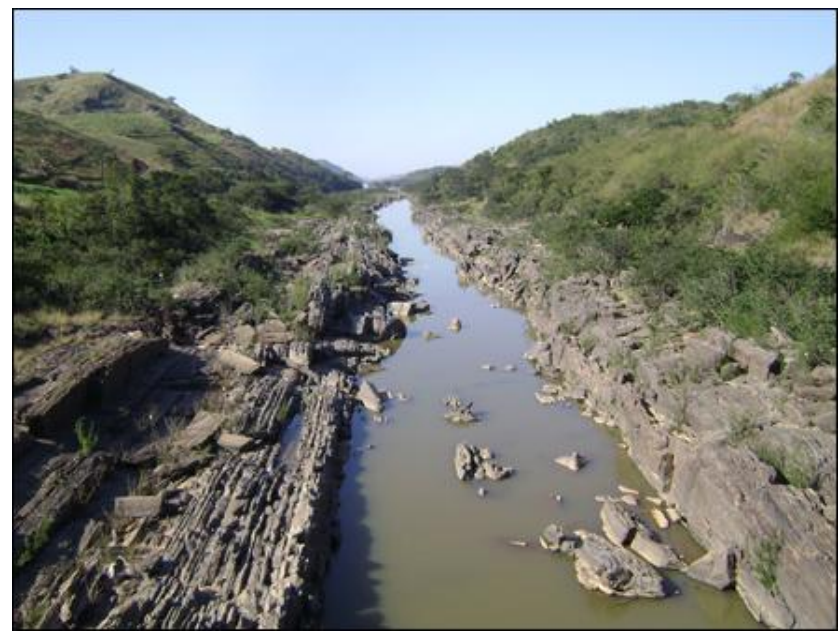

Figura 3: Afloramentos no leito do rio Paraíba do Sul evidenciando seu controle estrutural.

\section{Resultados}

\section{Aspectos Hidrogeomorfológicos}

Os rios tributários da margem norte, rio Pirapetinga e rio Angu, drenam sob forte controle litoestrutural, correndo em sua maioria na direção noroeste - sudeste, direção esta relativa aos alinhamentos de falhas e fraturas. São comuns, no entanto, os cotovelos de 90 graus, mudando para a direção nordeste em trechos que são orientados pela foliação. Ambos os rios descem de vales suspensos em suas cabeceiras, de direção nordeste e relevo de baixa amplitude, atravessando degraus mais abruptos em seus médios cursos, com direção predominantemente noroeste, até atingirem um compartimento topográfico mais rebaixado de colinas, antes de caírem encachoeirados no rio Paraíba do Sul. Estas cachoeiras próximas à foz dos rios Angu e Pirapetinga constituem níveis de base locais que suspendem os compartimentos colinosos em relação ao nível de dissecação do rio Paraíba do Sul.

Os afluentes da margem sul, por sua vez, apresentam-se com curta extensão descendo abruptamente do relevo suspenso da Serra de Santa Rita, na região da cidade de Santa Rita da Floresta, diretamente ao rio Paraíba do Sul. Nessa condição, 
destaca-se o córrego da Prata, com orientação nordeste em seu alto curso e sequenciados cotovelos para a direção noroeste até sua foz, também encachoeirada. Da mesma forma, este nível de base próximo à sua foz suspende um relevo de dissecação no interior do vale do córrego da Prata, porém de curta extensão. Pequenas drenagens rápidas desembocam diretamente no rio Paraíba do Sul, para jusante da foz do córrego da Prata, descendo das vertentes da Serra do Gavião encaixados em fraturas de direção noroeste. Ainda nesta margem, drenando toda a parte sul da área de influência, no reverso da Serra do Gavião, destaca-se o ribeirão das Areias. Este rio nasce na Serra de Santa Rita e também possui um compartimento de colinas suspenso em seu alto curso, que se estende com direção nordeste, desde a cidade de Santa Rita da Floresta até a montante do povoado de Boa Sorte. Para jusante, o rio desce abruptas encostas e, encaixado, ainda com direção nordeste, percorre um ambiente de colinas em nível topográfico mais baixo até sua foz. Os rios Jacutinga e São Primo, por sua vez, guardam, suspensos por níveis de base locais, compartimentos topográficos diferenciados, assim como os descritos para o córrego da Prata, rios Angu e Pirapetinga.

Vale ressaltar que, a montante dos níveis de base locais, citados acima, espraiamse sedimentos aluviais que agradam os fundos de vale em função da diminuição de energia de transporte desempenhada pelo nível de base.

O processo intempérico e erosivo ao longo da evolução geomorfológica dessa paisagem obedeceu, portanto, às diferenças de resistência litoestrutural da geologia, incluindo as diferenciações topográficas. Ou seja, as litologias menos resistentes intemperizaram e perderam seus materiais de acordo com os pulsos erosivos desencadeados por níveis de base rebaixados tectônica e erosivamente.

A abertura do Oceano Atlântico e o tectonismo responsável pelo rifteamento do planalto sudeste, citados anteriormente, provocaram pulsos erosivos que se perpetuam na paisagem até os dias atuais e permanecem ativos em algumas áreas, não tendo ainda atingido contundentemente todas as porções da superfície. Ou seja, os efeitos do pulso erosivo gerados pelo rebaixamento dos níveis de base se distribuem de maneira heterogênea na superfície, definindo ora porções suspensas relativamente isoladas do pulso erosivo, ora áreas rebaixadas intensamente erodidas, ajustadas aos níveis de base. Nesse sentido, a porção do terreno abatida neste trecho, denominada Graben de Itaocara, desencadeou, a partir da convergência de fluxos, papel detonador dos processos de dissecação para as bacias adjacentes. O recuo erosivo provocado por esse processo desenha domínios de relevo degradados formados por colinas côncaco-convexas, onde o trabalho erosivo está consolidado. Já nas bordas planálticas, nas quais o recuo erosivo ainda está se expandindo, os relevos apresentam-se escarpados com pontões rochosos proeminentes, como pães de açúcar. A montante destas frentes erosivas, voltamos a encontrar relevos de colinas dissecados e trabalhados em pulsos anteriores, suspensos por níveis de base locais, guardando um relativo isolamento dos pulsos erosivos. 
Foram criados, portanto, dez domínios geomorfológicos para a análise da superfície da área de influência, considerando as formas do relevo, erosivas e deposicionais, a declividade e a amplitude de relevo. 


\section{Domínios Geomorfológicos}

Em função dos processos evolutivos de dissecação deste relevo foram criados os seguintes domínios geomorfológicos para a área de influência do empreendimento, conforme Figura 4:

Domínio 1: Colinas Baixas associadas à calha do Rio Paraíba do Sul.

Domínios 2, 3, 4 e 5: Colinas Baixas do médio curso dos rios Pirapetinga, Angu, São Primo e Córrego da Prata.

Domínios 6, 7 e 8: Degraus, Serras Isoladas e Pães de Açúcar, sul, norte e central. Domínios 9 e 10: Vales Suspensos do Rio Angu e do Ribeirão das Areias.

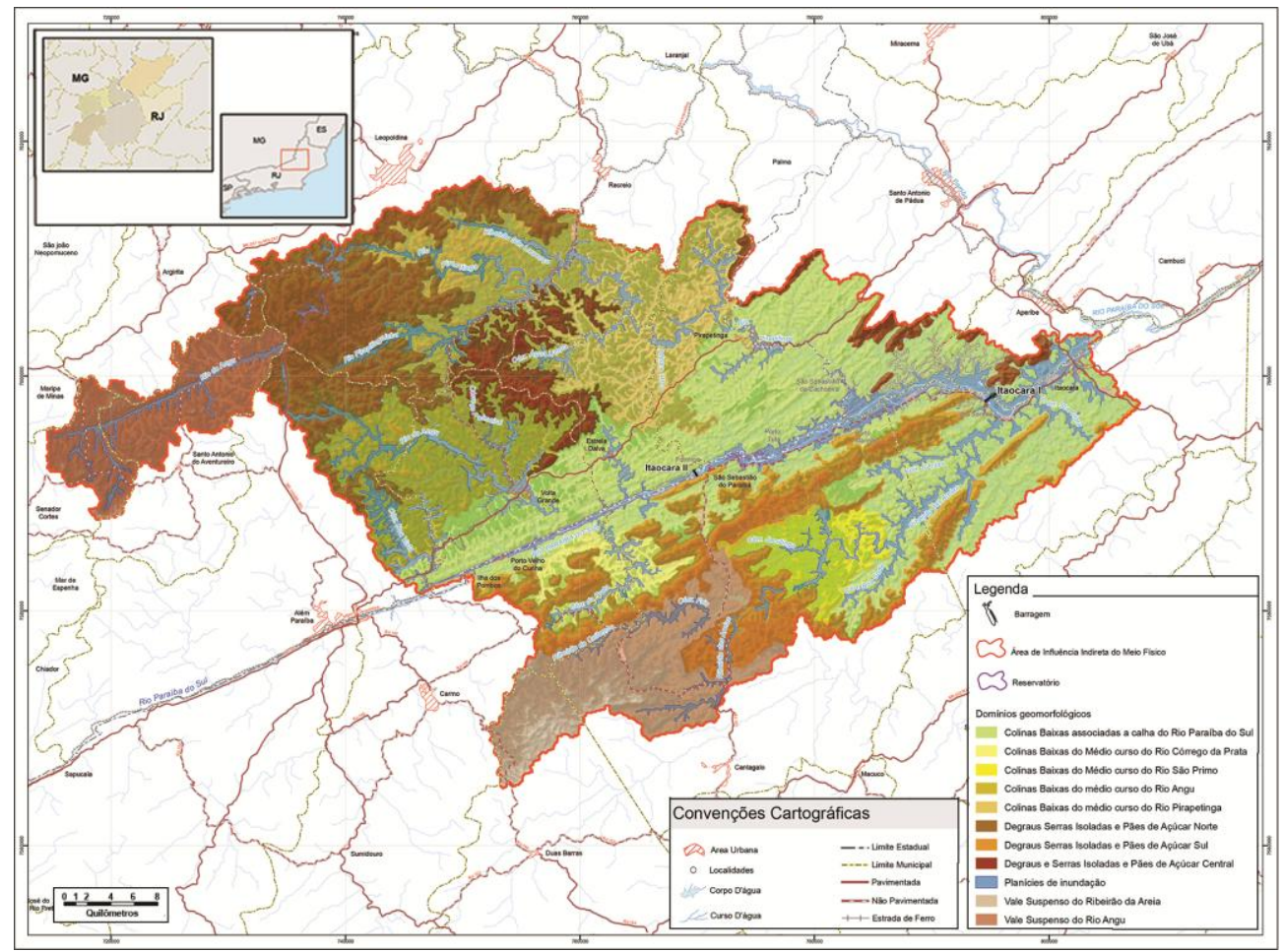

Figura 4: Mapa de domínios geomorfológicos da área de influência do empreendimento.

\section{Domínio 1: Colinas Baixas associadas à calha do rio Paraíba do Sul}

Este domínio está associado ao relevo de colinas baixas reguladas pelo nível de base do próprio rio Paraíba do Sul. Estende-se ao longo da calha principal do rio e adentra os tributários Valão do Barro Preto, Santa Clara e Caités. Limita-se ao norte pelos níveis de base que suspendem os médios cursos do rio Angu e Pirapetinga. As colinas apresentam amplitude de relevo pouco maiores que $100 \mathrm{~m}$ e as encostas não expressam grandes declividades. As geometrias são predominantemente convexas, 
porém com grande quantidade de concavidades nas cabeceiras de canais de primeira ordem ou eixos de ordem zero. As planícies de inundação repletas de alvéolos entremeiam estas colinas espraiando sedimentos fluviais retidos pelo nível de base do rio Paraíba do Sul (Figura 5). Este domínio ressalta sua importância por ser diretamente afetado pela construção do reservatório, alterando localmente as dinâmicas hidro-erosivas.

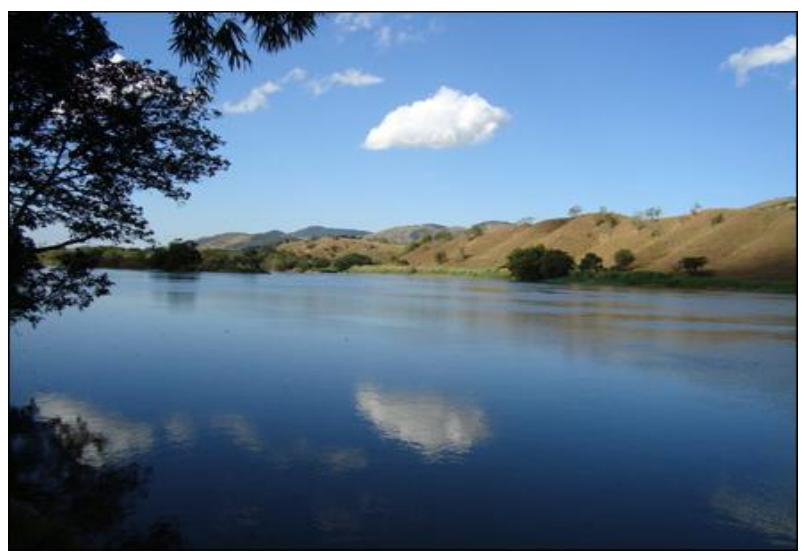

Figura 5: Aspecto das colinas próximas ao rio Paraíba do Sul.

\section{Domínio 2: Colinas Baixas do médio curso do rio Pirapetinga}

Também formado por colinas de baixa amplitude, este domínio está regulado pela cachoeira formada no estrangulamento do rio Pirapetinga pela Serra da Bolívia. Este degrau define seu limite sul, enquanto para norte e oeste este domínio se estende até as frentes de dissecação nas serras de Itatinga e Passa-Tempo, ao norte, e Palmeiral e Boa Vista, a oeste, estas últimas inseridas no domínio 8. Na porção leste, o limite é dado pelo divisor da bacia que, por sua vez, apresenta desnivelamentos um pouco maiores, mas que não foram separados como outro domínio. A morfologia é novamente côncavo-convexa, porém com topos convexos alongados de baixíssima declividade (Figura 6). 


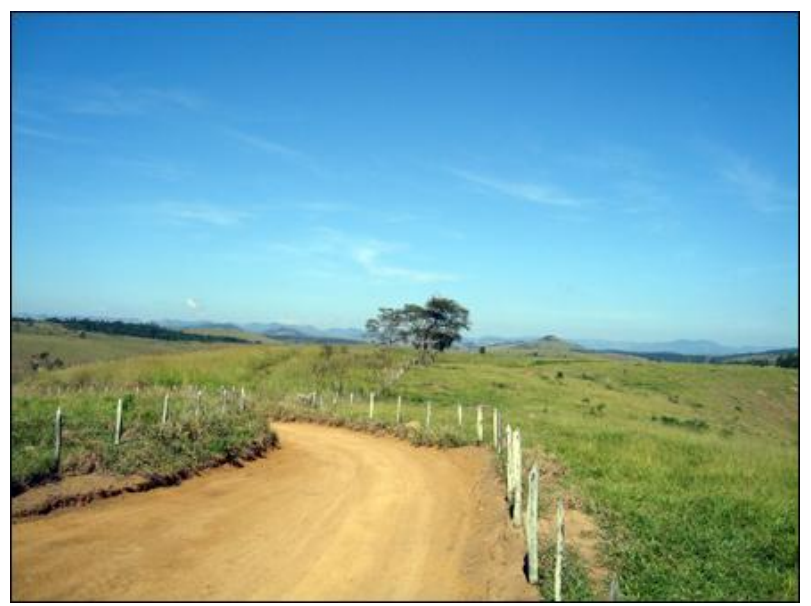

Figura 6: Aspecto dos topos convexos alongados das colinas no médio curso do rio Pirapetinga.

A amplitude de relevo varia de um fundo de vale em $200 \mathrm{~m}$ e topos nas cotas em torno de $300 \mathrm{~m}$. Para montante, como era esperado, os desnivelamentos se tornam um pouco maiores, atingindo, já próximo ao domínio 7, $200 \mathrm{~m}$ de amplitude. As declividades das encostas continuam suaves, variando em torno de 20 graus, e os fundos de vale apresentam-se abertos com sedimentação fluvial, salvo para os trechos de encaixe do rio Pirapetinga, já próximo a porção sul do domínio, em direção à cachoeira que o limita.

\section{Domínio 3: Colinas Baixas do médio curso do rio Angu}

Semelhante ao anterior, o domínio das colinas baixas do médio rio Angu apresenta-se pouco menos extenso, limitado ao norte pelo nível de base que suspende o vale do alto rio Angu (próximo à cidade de São Domingos). Ao sul, o domínio está limitado pelo nível de base, a jusante da cidade de Volta Grande. A leste, a mesma Serra do Palmeiral limita a ocorrência destas colinas. A amplitude de relevo apresenta-se um pouco mais elevada em todo o domínio, passando dos $150 \mathrm{~m}$ e chegando a $200 \mathrm{~m}$, para as porções mais ao norte. A menor extensão espacial do domínio o torna mais próximo das topografias mais elevadas dos domínios limítrofes. Os topos convexos e alongados não são tão comuns, restringindo-se em topos isolados, dissecados pela drenagem e repletos de concavidades (Figura 7). 


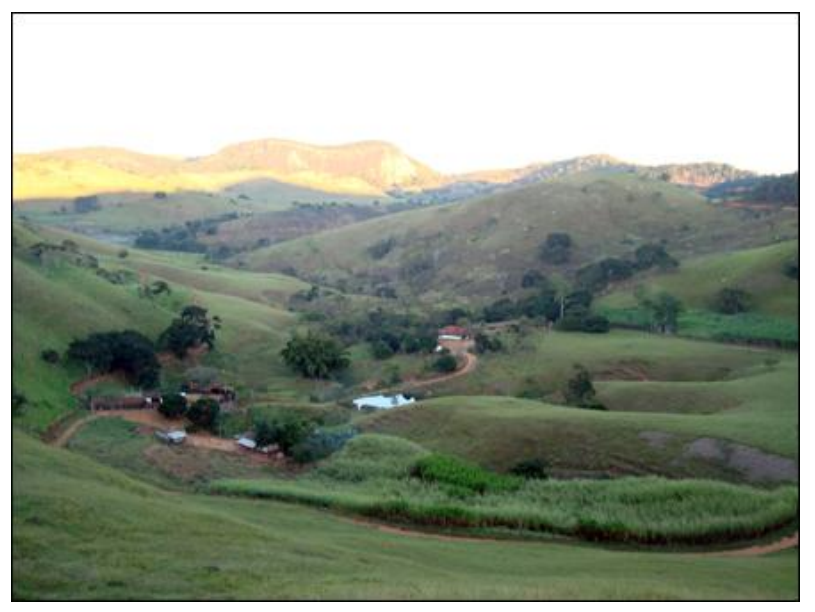

Figura 7: Aspecto das colinas próximas à Trimonte, no médio curso do rio Angu, onde o relevo mais recortado isola o topo das colinas.

Obs.: Nota-se, ao fundo, as elevações já pertencentes ao domínio: escarpas, serras isoladas e pães de açúcar norte.

\section{Domínio 4: Colinas Baixas do médio curso do rio São Primo}

De dimensão espacial menor que o domínio anterior, as colinas no médio curso do rio São Primo configuram-se como um nível suspenso antes de sua queda no córrego das Areias e, por isso, livre da dissecação atual no domínio 1 de colinas baixas. Este pequeno trecho suspenso se estende até a vertente sul da Serra do Gavião, marcado com um relevo escalonado em compartimentos ajustados a níveis de base locais. As amplitudes entre os fundos de vale e topos variam de 100 a $200 \mathrm{~m}$, constituindo encostas não muito longas de declividade média a baixa. (Figura 8).

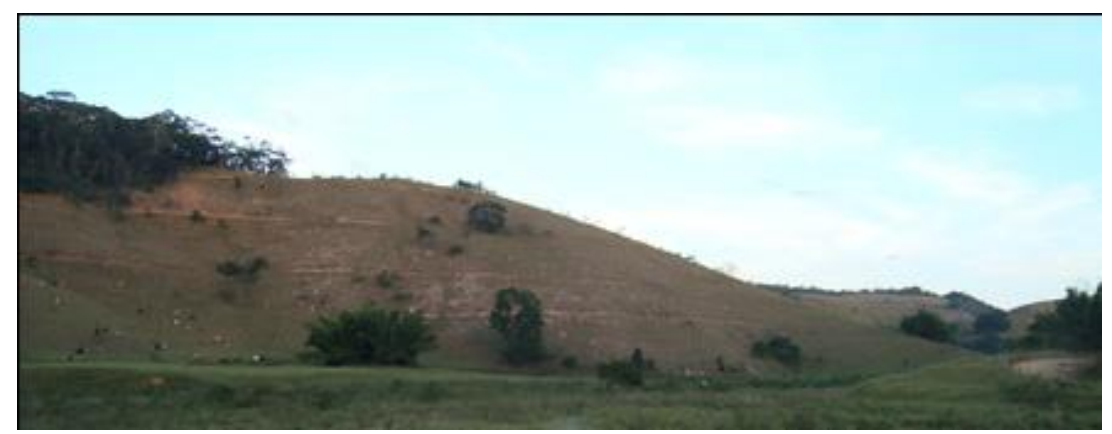

Figura 8: Aspecto das colinas no vale suspenso do córrego das Areias, próximo a sub-bacia do rio São Primo. 


\section{Domínio 5: Colinas Baixas do médio curso do Córrego da Prata}

Embutido no fundo de vale do córrego da Prata, este domínio apresenta-se escalonado por níveis de base locais que descem dos contrafortes da Serra de Santa Rita até o nível de base que derrama suas águas para o rio Paraíba do Sul. O desnível entre o fundo de vale e o topo das colinas é de 100 a 150 m. Este domínio representa a dissecação do pulso erosivo do rio Paraíba do Sul escavando os contrafortes da Serra. Este trabalho erosivo deixou remanescentes em forma de colinas suaves em pequenos topos convexos, isoladas das vertentes íngremes serranas. Acima destes já passamos ao domínio 6 de escarpas, serras isoladas e pães de açúcar sul. As declividades são relativamente mais acentuadas por suas encostas estarem conjugadas ao alinhamento serrano das serras de Santa Rita e do Português (Figura 9).

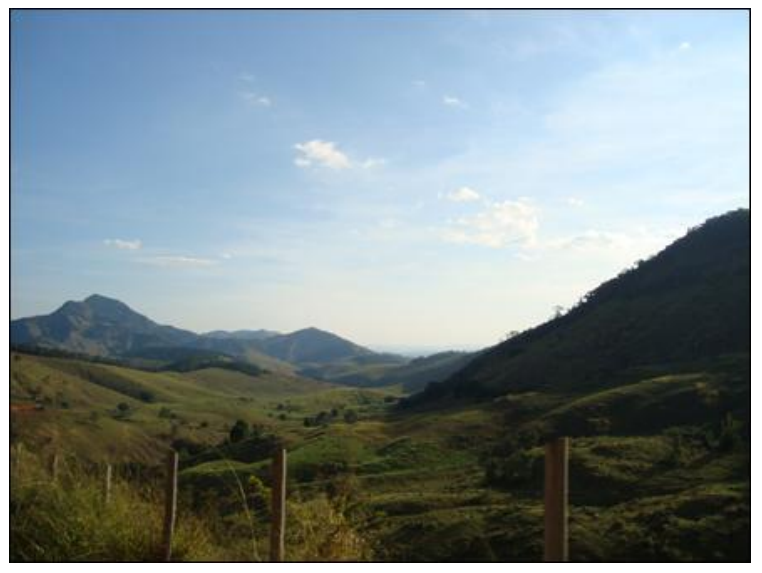

Figura 9: Aspecto das colinas no vale do córrego da Prata, em que nota-se a conjugação com as vertentes íngremes da Serra de Santa Rita e da Serra do Português.

\section{Domínio 6: Degraus, Serras Isoladas e Pães de Açúcar Sul}

Este domínio é formado pelas Serra do Gavião, vertentes da Serra de Santa Rita e da Serra do Português, Serra da Caledônia e degraus da passagem do vale suspenso do córrego das Areias para o domínio 4 de colinas baixas do médio curso do rio São Primo. Este domínio é caracterizado por vertentes íngremes, muitas vezes com afloramentos rochosos, onde o processo erosivo promove o recuo das vertentes em direção aos vales suspensos nos domínios adjacentes. Nessas áreas, a declividade acentuada define uma dinâmica erosiva mais intensa, associada a movimentos de massa e avalanches detríticas. A amplitude de relevo eleva-se para $300 \mathrm{~m}$, chegando às cotas altimétricas de 500 e $600 \mathrm{~m}$. Os topos de morro são contínuos e alongados, garantindo os alinhamentos serranos da região. Nestas vertentes, as geometrias côncavas são encontradas abundantemente, revelando as frentes de dissecação do relevo. Diferente dos ambientes de colina, as concavidades que acomodam os eixos 
de drenagem apresentam-se alongadas, definindo a alta energia dos processos erosivos (Figura 10). É notório o controle estrutural do alinhamento destas concavidades, acompanhando ora a direção de fraturas NW, ora foliações NE, bem como seu trabalho de rebaixamento dos divisores, isolando topos pontiagudos.

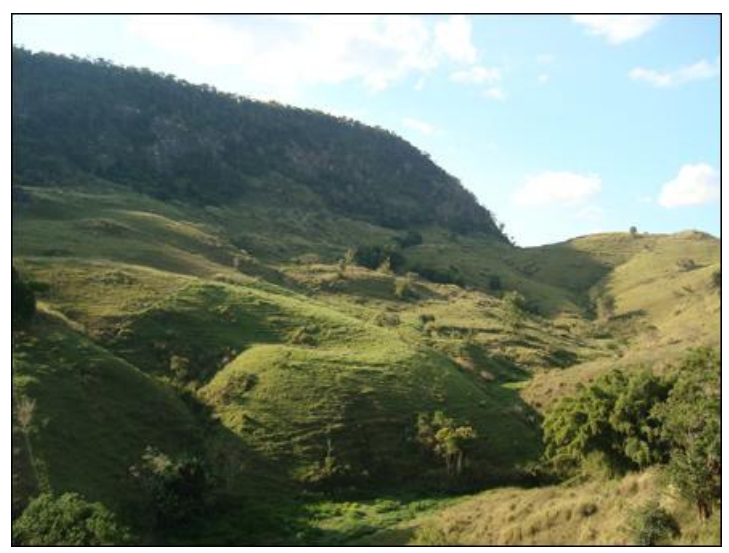

Figura 10: Aspecto das vertentes íngremes dos alinhamentos serranos repletos de concavidades alongadas, na Serra do Português.

\section{Domínio 7: Degraus, Serras Isoladas e Pães de Açúcar Norte}

Semelhante às feições encontradas no domínio anterior, as serras da porção norte apresentam topos nas cotas de $600 \mathrm{~m}$ caindo para fundos de vale nas cotas em torno de $300 \mathrm{~m}$. As vertentes configuram-se íngremes e as concavidades alongadas. A alta energia de processos erosivos tipo movimentos de massa se expressa comumente na paisagem (Figura 11).

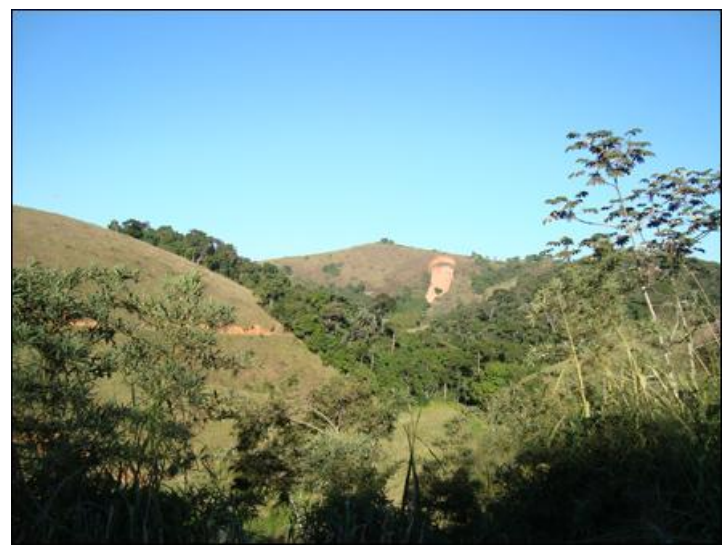

Figura 11: Vertentes íngremes na porção norte da área de influência revelando o entalhamento dos vales $e$ movimento de massa na encosta. 


\section{Domínios 8: Degraus, Serras Isoladas e Pães de Açúcar Central}

O domínio se diferencia dos dois anteriores por estar cercado de colinas, e representa remanescentes da dissecação promovida em seu entorno. Isolado pela coalescência das concavidades que rebaixaram seus divisores, este domínio é marcado pela ocorrência de pães de açúcar das serras dos Palmeirais e da Boa Vista (Figura 12). As vertentes íngremes expõem afloramentos rochosos e encaixam cabeceiras de drenagens alongadas. Estas feições terminam abruptamente em depósitos de tálus, que se articulam aos fundos de vale dos rios tributários dos rios Angu e Pirapetinga.

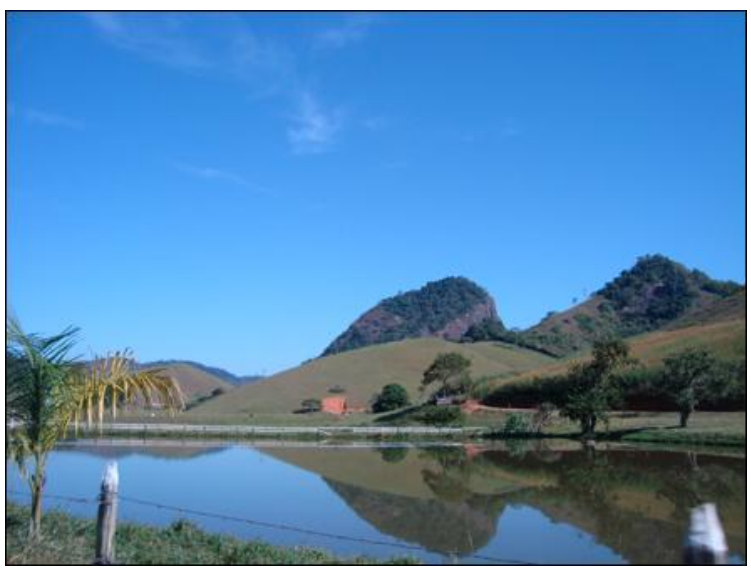

Figura 12: Pães de açúcar na Serra da Boa Vista.

\section{Domínios 9: Vales Suspensos do Rio Angu}

A paisagem geomorfológica do vale suspenso do rio Angu apresenta baixa amplitude de relevo entre os topos, que atingem cotas de $700 \mathrm{~m}$, e o fundo de vale, em $500 \mathrm{~m}$, representada por um suave ambiente de colinas. A orientação da drenagem do rio Angu neste trecho está associada à foliação NE até o limite leste do domínio. Abaixo deste nível de base, o rio Angu muda bruscamente seu curso e sua declividade, formando um cotovelo norte-sul em direção ao seu médio curso. Este cotovelo representa o processo de captura de drenagem advindo do recuo erosivo do domínio a jusante, que continua trabalhando no recuo do nível de base que suspende o vale em questão.

Os alinhamentos das serras que delimitam os divisores deste vale também seguem a orientação da foliação geológica e são recortados por concavidades alinhadas ortogonalmente em planos de fratura (NW). As concavidades representam complexos de rampa com estrangulamentos na base e fundos preenchidos de 
material coluvionar. Por sua vez, o fundo de vale é preenchido por depósitos fluviais em planície de inundação, sem evidência de terraços. A ausência de terraços demonstra a evolução geomorfológica ajustada ao nível de base da bacia, refletindo a inexistência de pulsos erosivos recuando remontante. Tal planície de inundação se caracteriza por uma extensa área no entorno da drenagem, com mais 300 metros de largura em alguns trechos do vale (Figura 13).

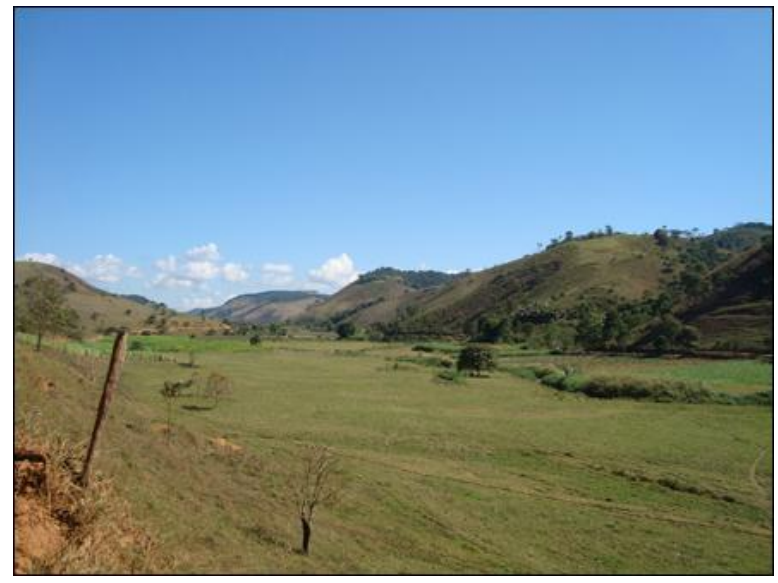

Figura 13: Aspecto do vale suspenso do rio Angu nas proximidades da cidade de São Domingos. Detalhe das concavidades estranguladas na base das drenagens afluentes.

\section{Domínio 10: Vale Suspenso do Ribeirão das Areias}

A principal drenagem deste compartimento é o ribeirão das Areias, que possui um vale suspenso na cota de $450 \mathrm{~m}$ e divisores nas cotas entre 800 e $900 \mathrm{~m}$. Paralelo ao rio Paraíba do Sul, este vale suspenso apresenta uma paisagem marcada pelo relevo de colinas com declividades suaves e topos convexos (Figura 14). Em sua porção oeste estão as maiores altitudes, mas que, no entanto, revelam apenas colinas mais elevadas e com maior comprimento de encostas. Como a foz deste rio no rio Paraíba do Sul se faz apenas a jusante do reservatório, acreditamos que as feições erosivas e deposicionais deste compartimento não devem influenciar na funcionalidade do reservatório, sendo influente no trecho a jusante do barramento. 


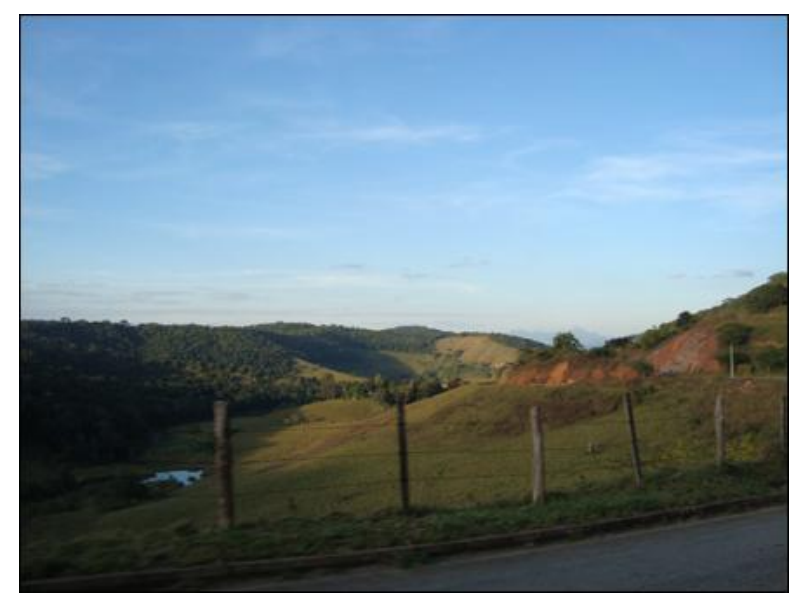

Figura 14: Aspecto do relevo de colinas no vale suspenso do Ribeirão das Areias.

\section{Considerações a respeito dos processos erosivos na área de estudo}

De maneira geral, no que se refere ao ordenamento e planejamento do uso das terras destinadas à agropecuária, característica comum na área de influência da UHE Itaocara, é importante que se respeite a vulnerabilidade natural dos solos, assim como o perfil sociocultural das comunidades rurais. Em virtude dos processos históricos de ocupação da região, que incluem o modo inadequado de cultivo do café em linhas ao longo das encostas sem respeitar as curvas de nível, levou-se a cafeicultura rapidamente à decadência, reduzindo a extensão e a importância econômica do café em menos de um século de exploração. Enquanto avançava a decadência da cafeicultura, a pecuária se desenvolvia, substituindo a agricultura como atividade econômica principal até meados do século XX, quando o país entra na era industrial, transformando a região de condição de economia e população essencialmente rurais em uma de condição medianamente urbana em menos de três décadas (DEAN, 1997).

É possível constatar que o processo de ocupação e uso do solo na Bacia do Rio Paraíba do Sul, intensificado nos últimos 200 anos a partir da cafeicultura, resultou na completa transformação de uma paisagem predominantemente florestal, para outra dominada pela vegetação de gramíneas características das pastagens, embora grande parte da área classificada como pastagem já seja constituída por terras degradadas, sem uso (ANA \& COPPETEC, 2002).

Conforme o trabalho citado acima, realizado conjuntamente pela Agência Nacional de Águas e a Fundação COPPETEC (2002), o trecho fluminense da bacia é o que detém a maior extensão de remanescentes da Mata Atlântica, embora o percentual de florestas em relação ao território da bacia seja muito baixo, cerca de 13\%. O trecho mineiro da bacia do Paraíba do Sul é o que se encontra mais 
desmatado e o que apresenta a maior extensão e o maior percentual de áreas de campo/pastagem - aproximadamente $80 \%$.

A distribuição da cobertura florestal nas sub-bacias que contribuem para a bacia do Paraíba do Sul certamente é um fator de grande relevância para a gestão dos recursos hídricos e do solo. A sub-bacia do rio Pirapetinga, por exemplo, possui percentual de cobertura florestal de 6,5\%. A sub-bacia do rio Angu possui valores médios de $5 \%$ e a sub-bacia do Ribeirão das Areias, por sua vez, possui posição de destaque, com cerca de $16 \%$. De forma geral, a região que engloba as sub-bacias que contribuem para o rio Paraíba do Sul na área entre Três Rios e o município de Itaocara possui percentual médio de cobertura florestal de 8,5\% (ANA \& COPPETEC, 2002).

Além da cobertura vegetal, outros fatores influenciam no desencadeamento de processos erosivos. Segundo Guerra (2000), para se estudar as feições erosivas é preciso levar em consideração os seguintes fatores: compartimentação geomorfológica; declividade dos terrenos; características meteorológicas (principalmente pluviosidade); aspectos geológicos estruturais; uso e ocupação do solo; classes de solo e seus graus de erodibilidade. Aos processos de erosão laminar, em sulcos incisos e voçorocamentos, que integram os processos de transporte de sedimentos da dinâmica das encostas, somam-se também os deslizamentos e escorregamentos, movimentos coletivos de massa com arraste de grande volume de material intemperizado.

O desencadeamento dos processos que levam à erosão dos solos pode ser acarretado tanto pelo manejo inadequado da terra, como observado na área de influência do empreendimento, quanto por causas naturais. Por meio de observações em campo foi possível denotar que os processos de erosão linear, caracterizados pelo escoamento pluvial concentrado, são comuns na área, sendo identificáveis em vários pontos na área de influência do futuro reservatório. Os principais tipos observados foram sulcos e ravinas relacionadas às práticas mal conduzidas de pasto, voçorocas e movimentos de massa.

\section{Sulcos Erosivos e Ravinas}

Os mecanismos de detonação desse processo se iniciam pelo escoamento superficial provocado pela diminuição da capacidade de infiltração. Esta condição é atingida pela compactação dos solos, pelo pisoteio do gado e pelo processo de "splash erosion", desencadeado em solos expostos. O impacto direto das gotas desestruturam os agregados do topo do solo, soltando partículas menores que obstruem os poros do solo dificultando o processo de infiltração. A precipitação que 
excede a capacidade de infiltração dos solos escoa superficialmente removendo as partículas minerais e a matéria orgânica responsável pela fertilidade dos solos

(HORTON, 1945; DUNNE \& LEOPOLD, 1978; GUERRA, 1991). O escoamento superficial se concentra em sulcos que, aprofundando-se, originam as ravinas.

No geral, o uso e manejo do solo nesta região são caracterizados pela utilização do solo pela agropecuária sem um plano de manejo adequado, com a retirada da vegetação e muitas vezes com uso de queimadas sucessivas. O produto resultante dessa interação gera problemas na capacidade produtiva do solo, por exemplo, a perda de matéria orgânica e de nutrientes, a alteração da micromorfologia do topo do solo, assim como a redução na capacidade de infiltração da água e a detonação de processos superficiais de erosão do solo. Grandes quantidades do melhor solo (Horizonte A) são transportadas pelo escoamento superficial, reduzindo sua fertilidade, o que, certamente, prejudica a produção.

Na margem esquerda do rio Paraíba do Sul, onde as encostas se apresentam um pouco mais distantes da calha do rio, forma-se uma planície de inundação considerável que se encontra ocupada por agricultura de subsistência ou para mercado local, pastagens de tamanho reduzido e pequenas atividades de exploração de saibro e areia. Nas áreas destinadas à pastagem foram observadas feições erosivas características de erosão laminar e em sulcos; e nas áreas de atividade mineral é frequente a abertura de cortes que podem facilitar a ocorrência de deslizamentos ou recuos por voçorocamento.

\section{Voçorocas}

Este processo erosivo é desencadeado por fluxos subsuperficiais do escoamento da água na zona aerada dos solos, assim como por fluxos subterrâneos na zona saturada. A existência de faces de exfiltração, seja pelo corte natural de uma incisão fluvial ou por atividades antrópicas para construção de estradas ou casas, permite a saída desses fluxos que migram pelas encostas em direção aos fundos de vale. Dependendo da poropressão exercida na face de exfiltração, tais fluxos podem desencadear processos erosivos em forma de pipes, chegando à formação de túneis erosivos. Os túneis erosivos recuam remontante e, sofrendo colapso de seus tetos, abrem o processo de voçorocamentos, podendo ocorrer tanto em encostas como em fundos de vale (COELHO NETTO, 2003).

Os domínios geomorfológicos em que pulsos erosivos desencadeados pelo rebaixamento de níveis de base ocorrem criam faces de exfiltração pela incisão fluvial, o que desencadeia, pela expansão da rede de drenagem, processos de voçorocamento. Na área de influência não são comuns voçorocas desencadeadas por pulsos erosivos de rebaixamento de nível de base, com exceção de uma diagnosticada no vale do córrego da Lage, paralelo ao córrego da Prata. 


\section{Movimentos de Massa}

Movimentos de massa são processos de mobilização por gravidade do material intemperizado que recobre o substrato geológico, podendo ter ou não influência de poropressões positivas da água no solo. Vale ressaltar que tais processos são comuns em áreas de pastagens com gramíneas que possuem padrão de enraizamento homogêneo. A zona de raízes atinge poucas dezenas de centímetros no solo (30 a $40 \mathrm{~cm}$ ) e constitui um horizonte de infiltração relativamente mais permeável que a zona sub-radicular, imediatamente abaixo. A descontinuidade hidráulica gerada por essa diferença de permeabilidade é capaz de gerar poropressões críticas a ponto de promover o destacamento do solo acima desta zona. Dá-se origem, então, a um deslizamento de pouca profundidade, mas que contribui consideravelmente com sedimentos ao assoreamento da rede hidrográfica.

Em termos geomorfológicos, a mudança das unidades da paisagem que contém vales suspensos entulhados para a paisagem composta por relevo mais acentuado, com pontões rochosos gerados a partir do rebaixamento do nível de base, demonstra característica que propicia a formação de interflúvios de topo convexo e vales que, condicionados pelos substratos geológicos, correm encaixados em litoestruturas de menor resistência intempérica. Nestes domínios de pães de açúcar e degraus de serras, o recuo erosivo das vertentes ocorre em grande parte por esses mecanismos.

Alguns processos de movimentos de massa observados ainda apresentam evolução ativa, pois não foram parcialmente obliterados e/ou retidos pela retomada natural da vegetação arbustiva e graminóide. Em alguns casos pode se observar a cobertura de gramíneas nas cicatrizes dos movimentos de massa. Os principais tipos de escorregamento na área são caracterizados pelo carreamento de material do solo pouco profundo em encostas convexas cobertas por gramíneas. Esses movimentos de massa aparentam ocorrer de forma sazonal no período chuvoso e, em menor escala, proporcionados pela descontinuidade hidráulica no fim da zona radicular das gramíneas. Os solapamentos e desbarrancamentos promovem também movimentos de massa em função da abertura de estradas ou nas margens dos cursos d'água, definindo movimentos rotacionais.

\section{Concavidades}

Vale ressaltar o papel das concavidades na evolução do relevo e na ocorrência de processos erosivos. Segundo Coelho Netto (2003) e Avelar e Coelho Netto (1992), a carga total de poropressões das águas subsuperficiais indicou a convergência dos fluxos d'água em direção à base inferior do eixo de concavidades estruturais (aquelas controladas pelas estruturas geológicas). Em alguns casos, na cabeça destes pequenos canais geralmente ocorrem túneis erosivos que evoluem regressivamente, podendo dar origem a voçorocas. 
Nos denominados anfiteatros (cabeceiras de drenagem), desenvolvem-se os "complexos de rampa", descritos por Meis et al. (1981) como as áreas de encostas com geometria côncava, constituídas de feições erosivas em suas porções mais altas da encosta e feições de acumulação de colúvios sucessivos nos seus eixos. Nessas concavidades são comuns também movimentos de massa, associando em si processos erosivos de diversas naturezas e representando, assim, as feições de evolução denudacional das paisagens. Esses processos erosivos podem, ainda, se tornar mais intensos devido, certamente, ao mau uso dos solos por atividades antrópicas.

De uma forma geral, as feições erosivas côncavas aparentes nas bacias de drenagem afluentes desse trecho do rio Paraíba do Sul apresentam-se bastante reafeiçoadas e suavizadas em forma de pequenos eixos de drenagem que hoje permanecem estabilizados. As feições erosivas ativas estão associadas ao mau uso do solo atual, principalmente provocadas por sulcos erosivos e ravinamentos.

\section{Considerações Finais}

O mapeamento geomorfológico apresentado se baseou em uma abordagem que considera a importância do nível de base local na compartimentação do relevo. Tal compartimentação pode ser associada a domínios de dissecação que correspondem às áreas das superfícies topográficas da bacia de drenagem reguladas por um nível de base local. Os domínios geomorfológicos aqui descritos estão associados a estes compartimentos escalonados por knickpoints, em que os processos e dinâmicas erosivas particulares estão inseridos e intimamente relacionados.

Nesse sentido, o mapeamento apresentou dez domínios resultantes da evolução de longo tempo, influenciados pelos pulsos erosivos associados ao rebaixamento dos níveis de base. Este retrabalhamento dos níveis de base ocorre em função do histórico tectônico da área, bem como de suas resistências litológicas e estruturais diferenciais.

Segundo a análise dos mapas e dados primários levantados em campo, na área de estudo foram encontradas áreas antropizadas classificadas como processos erosivos laminares moderados e processos erosivos lineares de média a grande intensidade, além de algumas feições erosivas em voçorocas e movimentos de massa nos domínios de declividade mais abrupta. Nos ambientes junto à calha do rio Paraíba do Sul, as feições erosivas observadas estavam concentradas principalmente na margem direita do rio.

Seria de grande valor iniciativas de recuperação de áreas degradadas na bacia do Paraíba do Sul, sobretudo nos domínios geomorfológicos de Colinas baixas 
associadas à calha do rio Paraíba do Sul, que definem processos de dissecação mais intensos influenciados pelo mau uso do solo, e também nos domínios de Degraus, Serras Isoladas e Pães de Açúcar, onde predominam eventos de movimentos de massa, necessitando, portanto, de interferências da engenharia geotécnica e estudos de risco geológico. A análise dos processos erosivos indica, então, as áreas prioritárias que necessitam de projetos que visem à proteção dos mananciais, de modo a garantir a qualidade da água e a sustentabilidade do empreendimento.

\section{Agradecimentos}

O presente artigo é proveniente das pesquisas realizadas para a empresa Ecology and Environment do Brasil Ltda., responsável pelo processo de licenciamento ambiental do mencionado projeto de hidrelétrica, e para a empresa EcoBrand Gestão Ambiental, responsável pela elaboração das análises do meio físico da área,para as quais são dirigidos os agradecimentos pela cessão do material de pesquisa e pela oportunidade de realização do trabalho.

\section{Bibliografia}

AB'SABER, A. N. (1957) O problema das conexões antigas e da separação da drenagem do Paraíba e do Tietê. Geomorfologia 26, Instituto de Geografia da USP, São Paulo. pp. 38-49.

AB'SABER, A. (2003) Os domínios de natureza no Brasil: potencialidades paisagísticas. São Paulo: Ateliê Editorial.

AGÊNCIA NACIONAL DE ÁGUAS \& FUNDAÇÃO COPPETEC. (2002) Projeto Gestão dos Recursos Hídricos da Bacia Hidrográfica do Rio Paraíba do Sul: análise de alternativas de crescimento demográfico, de evolução de atividades produtivas e de modificações dos padrões de ocupação do solo. Volume 2, 57p.

ALMEIDA, F. F. M. (1976) The system of continental rifts bordering the Santos basin, Brazil, An. Academia Brasileira de Ciências, no 48 (supl.). pp.15-26,

ALMEIDA, F. F. M. de; HASUI, Y.; BRITO-NEVES B. B. de; FUCK R. A. (1981) Brazilian Structural Provinces: an introduction. Earth-Sci. Ver. pp. 1-29.

ASMUS, H. E. \& FERRARI, A. L. (1978) Hipótese sobre a causa do tectonismo cenozóico na região sudeste do Brasil. Projeto REMAC, 4. pp. 75-88.

AVELAR, A. S. \& COELHO NETTO, A. L. (1992) Fraturas e o desenvolvimento de unidades côncavas no médio vale do rio Paraíba do Sul. Revista Brasileira de Geociências, Rio de Janeiro, v. 22, nº 2.

COELHO-NETTO, A. L. (2003) Evolução das cabeceiras de drenagem no Médio Vale do Rio Paraíba do Sul: a formação e o crescimento da rede de canais sob controle estrutural. Revista Brasileira de Geomorfologia. ano 4, n 2. pp. 69-100. 
COMPANHIA DE PESQUISA DE RECURSOS MINERAIS (CPRM). Geomorfologia do estado do Rio de Janeiro. Ministério de Minas e Energia: Projeto Rio de Janeiro.

DEAN, W. (1996) A Ferro e Fogo: A história da devastação da Mata Atlântica Brasileira. São Paulo: Companhia das Letras.

DUNNE, T. \& LEOPOLD, L. (1978) Water in Environmental Planning. Ed. John Wiley \& Sons Ltd.

FREITAS, M. M. (2007) Evolução da Paisagem Geomorfológica. In: RUA, J. (Org.) Paisagem, Espaço e Sustentabilidades: uma perspectiva multidimensional da geografia. Rio de Janeiro: Editora PUC Rio. pp. 91-128.

FREITAS, M. M., EIRADO, L. G., ALMEIDA, J., TUPINAMBÁ, M. (1999) Landscape Mosaic from Cenozoic Tectonic Events International In: Conference of Geomorphology.Anais Conference of Geomorphology, Rio de Janeiro, v.1.

GUERRA, A. J. T. (1991) Soil characteristics and soil erosion, with particular reference to organic matter content. Tese de doutorado, Universidade de Londres, 441p.

GUERRA, A. J. T. \& CUNHA, S. B. (2000) Geomorfologia e Meio Ambiente. Rio de Janeiro: Ed. Bertrand Brasil.

HEILBRON, M.; VALERIANO, C. V.; VALLADARES, C.V.; MACHADO, N. (1995) A orogênese brasiliana no segmento central da Faixa Ribeira, Brasil. Revista Brasileira de Geociências, 25(4). pp. 249-266,

HEILBRON, M.; SOARES, A. C. P; CAMPOS NETO, M.; SILVA, L. C.; TROUW, R.; JANASI, V. Província Mantiqueira. In: MANTESSO-NETO, V.; BARTORELlI, A.; CARNEIRO. C. D. R.; BRITO NEVES, B. B. (Org.). (2004) Geologia do Continente Sul Americano: Evolução da Obra de Fernando Flávio Marques de Almeida. 1. ed. São Paulo: Beca Produções Culturais Ltda.,v. I. pp. 203-234.

HORTON, R.E. (1945) Erosional development of streams and their drainage basins, hydrophysical approach to quantitative morphology. Geological Society American Bulletin, vol. 56. pp. 275-316.

MEIS, M. R. M.; MOURA, J. R. \& SILVA, T. O. (1981) Os "complexos de rampa" e a evolução das encostas no planalto sudeste do Brasil. Anais da Academia Brasileira de Ciências, 53 (3).

MOURA, J. R. S. \& SILVA, T. M. Complexos de Rampa de Colúvio. In: CUNHA, S. B. \& GUERRA, A. J. T. (Org.). (1998) Geomorfologia do Brasil. Rio de Janeiro: Bertrand Brasil.

RICOMINNI, C.; SANT'ÀNA, L. G. \& FERRARI, A. L. (2004) Evolução Geológica do Rift Continental do Sudeste do Brasil. In: MANTESSO-NETO, A.; BARTORELli, A.; DALKÉ CARNEIRO, C.; BRITO-NEVES, B. B. (Org.). Geologia do Continente Sul Americano: Evolução da Obra de Fernando Flávio Marques de Almeida. São Paulo: Ed. Beca. 
ROSS, J. L. S. (1990) Geomorfologia, ambiente e planejamento. São Paulo: Ed. Contexto. . (2000) Geografia do Brasil. São Paulo: Ed. USP.

SCHOBBENHAUS, C. \& CAMPOS, D. A. (1984) A evolução da plataforma sulamericana no Brasil e suas principais concentrações minerais. SCHOBBENHAUS FILHO, C.; CAMPOS, D. A.; DERZE, G. R.; ASMUS, H. E. Geologia do Brasil: texto explicativo do mapa geológico do Brasil e da área oceânica adjacente incluindo depósitos minerais, escala 1:250.000. Brasília: DNPM. pp. 9-49.

SCHOBBENHAUS, C. \& NEVES, B. (2003) A geologia do Brasil no contexto da Plataforma Sul-Americana. In: BIZZI, L. A.; SCHOBBENHAUS, C.; VIDOTTI, R. M.; GONÇALVES, J. H. (Ed.). Brasília: CPRM. pp. 5- 25.

SONDOTÉCNICA \& EMPRESA DE PESQUISA ENERGÉTICA. (2007) Avaliação Ambiental Integrada dos aproveitamentos hidrelétricos da bacia hidrográfica do rio Paraíba do Sul. 4 volumes..

TUPINAMBÁ, M.; SILVA, L. G.; HEILBRON, M. (2003) O graben de Itaocara, Rio de Janeiro, sudeste do Brasil. In: IX Simposio Nacional de estudos tectônicos/III International symposium on tectonics, Buzios. Boletim de resumos. Rio de Janeiro: Sociedade Brasileira de Geologia. pp. 305-306. 